\title{
The Strategies of Maxim Flouting In Lincoln Movie Script
}

\author{
I Gede Bagus Ariwangsa Rahmastra ${ }^{1 *}$ I Gusti Ayu Gede Sosiowati ${ }^{2}$ \\ ${ }^{[12]}$ English Department, Faculty of Arts, Udayana University \\ [ariwangsara@gmail.com], ${ }^{2}$ [sosiowati@yahoo.com] \\ *Corresponding Author
}

\begin{abstract}
This undergraduate thesis entitled The Strategies of Maxim Flouting in Lincoln Movie Script. It was aimed to analyze maxim flouting in movie script. In more specific terms, it was aimed to identify the strategies applied and the reasons of maxim flouting by the characters in Lincoln movie script. Documentation method and note taking technique were used to collect the data. Qualitative method and descriptive technique, theory of cooperative principle by Grice (1975), and theory of rhetorical strategy by Grundy (2000) were used to analyze the data. Informal method and argumentative technique were used to descriptively present the data. All four types of maxim flouting were performed in the movie script. Among six strategies of maxim flouting, four strategies were applied in Lincoln movie script. They are: overstatement, metaphor, rhetorical question, and irony. Various reasons have lead the character to flouting the maxim, they are: demanding, offering, accusing, reprimanding, cursing, threatening, announcing, instructing, greeting, reporting, asserting, and insulting.
\end{abstract}

Key words: maxim flouting, strategies, reason

\begin{abstract}
Abstrak
Skripsi ini berjudul The Strategies of Maxim Flouting di Lincoln Movie Script. Tulisan ini bertujuan untuk menganalisa pelanggaran maxim dalam naskah film. Dalam istilah yang lebih spesifik, tulisan ini bertujuan untuk mengidentifikasi strategi yang diterapkan dan alasan karakter dalam naskah film Lincoln dalam melanggar maxim. Metode dokumentasi dan teknik pencatatan digunakan untuk mengumpulkan data. Metode kualitatif dan teknik deskriptif, teori prinsip kooperatif oleh Grice (1975), dan teori strategi retoris oleh Grundy (2000) digunakan untuk menganalisa data. Metode informal dan teknik argumentatif digunakan untuk menyajikan data secara deskriptif. Keempat jenis maxim dilanggar dalam naskah film. Di antara enam strategi maxim, empat strategi diterapkan dalam naskah film Lincoln, yaitu: pernyataan berlebihan, metafora, pertanyaan retoris, dan ironi. Berbagai alasan telah menyebabkan karakter untuk melanggar maxim, mereka adalah: menuntut, menawarkan, menuduh, menegur, mengutuk, mengancam, mengumumkan, menginstruksikan, memberi salam, melaporkan, menyatakan, dan menghina.
\end{abstract}

Kata kunci: melanggar maxim, strategi, alasan

\section{Background of the Study}

As a part of language function, conversation is becoming the most common part used by human. In order to do those functions well, there are some rules to be followed by the conversation participants. People should be able to be cooperative to each other in order to be successful in communicating through conversation. According to Grice (in Yule, 1996: 37), people have a successful conversation if they fulfill the Cooperative Principle that is elaborated into four sub-principles or maxims. 
People seem to be uncooperative by not fulfilling maxims; however, for some reason they actually do. For being uncooperative, the speaker tried to convey some hidden meanings and certain purposes behind the utterances.

It is very interesting to conduct this study to investigate the strategy and the reasons of the flouted maxims in the movie Lincoln to prove that the communications through conversation are still successful, although the people do not follow the rules of maxim to be cooperative.

\section{Problem of the Study}

a) What are the strategies of maxim flouting applied in the movie Lincoln?

b) What are the reasons of using maxim flouting in the movie Lincoln?

\section{Aims of the Study}

a) To identify the strategies of maxim flouting applied in the movie Lincoln.

b) To identify the reasons of using maxim flouting in the movie Lincoln.

\section{Research Method}

There are four aspects of research method applied in this study; they are: Data Source, Method and Technique of Collecting Data, Method and Technique of Analysing Data, and Method and Technique of Presenting Data.

\subsection{Data Source}

In this study, the data were taken from a movie script. Here, a movie entitled Lincoln was selected as the object of study. It is an American historical drama movie. The script was written by Tony Kushner. The movie was directed by Steven Spielberg and starring Daniel Day-Lewis as the President of United States of America, Abraham
Lincoln. The movie was released theatrically by Touchstone Pictures in North America on November 9, 2012. This movie was chosen as data source because it contains utterances indicating maxim flouting. Moreover, it was based on a true story and it could give a more realistic example of maxim flouting during conversation in movie dialogue. The forms of data in this research were the characters' conversations in the movie. They were the utterances uttered by the characters that contain maxim flouting.

\subsection{Method and Technique of Collecting Data}

The method in collecting the data used was documentation. The technique used was note taking with the following procedure: First, the movie was downloaded completed with the script. Second, the script was checked to confirm whether it matched with the movie. Third, the utterances were identified using the theory of cooperative principle proposed by Grice to limit which utterances perform maxim flouting. The collected data were used to answer the problems descriptively.

\subsection{Method and Technique of Analysing Data \\ In doing this study related to maxim} flouting, qualitative approach and descriptive technique were used. The procedures of data analysis were as follows: First, the interpretation was made in order to understand the situation and context in which the data occurred in the utterance. Second, the interpreted data were analysed in order to answer the formulated problems. In this step, a comprehensive analysis of the interpreted data was done. The types of maxim flouting were discussed using Grice's theory of cooperative principle in 1975 . The strategies of maxim flouting were 
discussed using Grundy's theory of rhetorical strategy in 2000. The reasons of maxim flouting were discussed based on the relationship between the linguistic context and non-linguistic or experiential context.

\subsection{Method and Technique of Presenting Analysis}

In presenting the data, informal method and argumentative technique were used. The procedures of data analysis presentation were as follows: First, the movie's screenshot when the utterance that contains maxim flouting was presented. Second, the dialog of conversation was presented; the utterance that contains the maxim flouting was typed in italic. Third, the interpretation and analysis of the data from each problem were presented descriptively in the form of textual description.

\section{Result and Discussion}

The result and discussion of this research gives one sample data in each strategy found in the script of the movie Lincoln. According to Grice (1975: 45), maximof Cooperative Principle are divided into: maxim of quantity, maxim of quality, maxim of relevance or relation, and maxim of manner.

According to Grundy (2000: 98-99), rhetorical strategies include tautology, metaphor, overstatement, understatement, rhetorical question, and irony.

5.1 Overstatement is the strategy that describes something stronger than what is warranted by the state of affairs described by using exaggeration.

\section{Data 1}

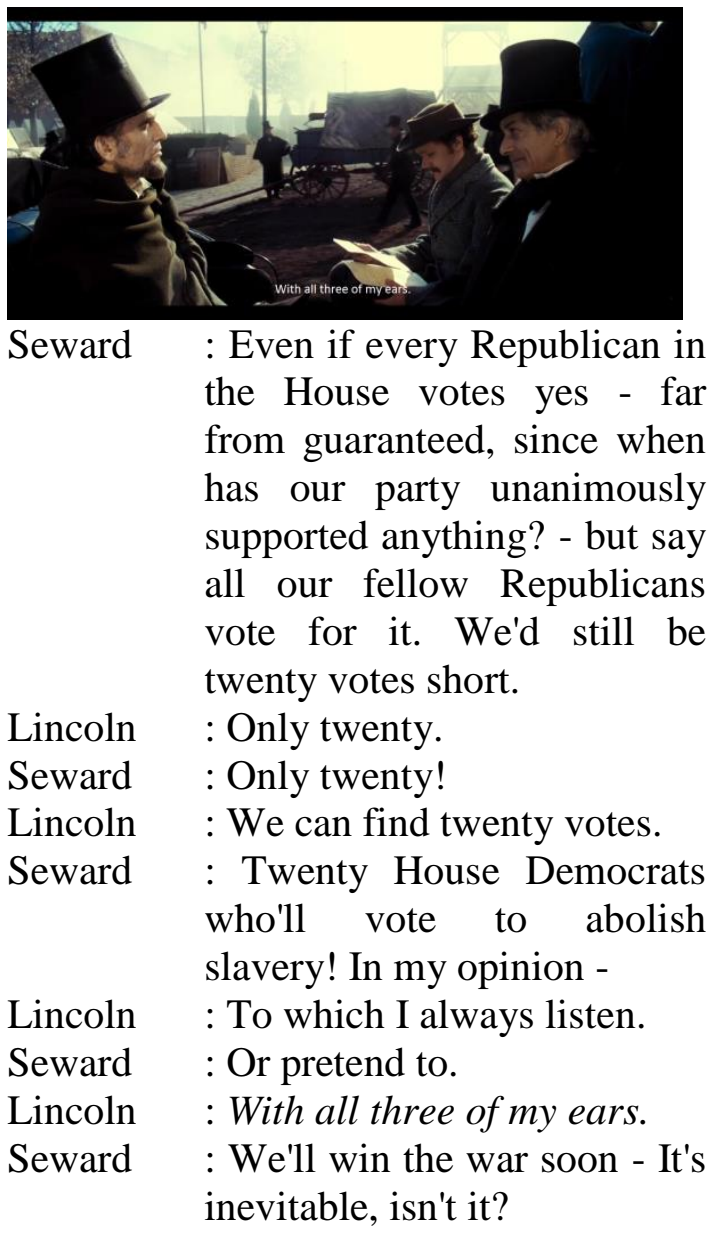

President Lincoln and the U.S. Secretary of State, William Seward, have a conversation about the thirteenth amendment. Thirteenth Amendment is the amendment of American constitution that banned slavery throughout the United States. Seward talks to President Lincoln about his pessimistic opinion of getting twenty more votes from the Democrat Party. When the president tries to convince him that they will be able to get those twenty votes, Seward starts to get mad about the president's optimistic act and about to say another opinion. Then, President Lincoln cuts it by saying that he always listens to Seward's opinion 'with all three of my ears'. The screenshot above shows President Lincoln's calm expression when he flouted the quality maxim to convince Seward to be optimistic that they will get the votes to pass the amendment. 
Moreover, the screenshot shows Seward's uncertain expression towards the president's utterance as well.

In this conversation, the president has done a quality maxim flouting since he does not make his contribution true for the purpose of the exchange. Overstatement takes place as a strategy of flouting the maxim quality in this exchange. The president states something that is false and lacks of adequate facts by exaggerating. The phrase 'three ears' is indicating his exaggeration. In this conversation, the point that he creates stronger than the actual state is the matter of hearing. By applying overstatement in this exchange the president tries to convince and assert Seward that he is always listens to Seward's political opinion with all the ability he has.

5.2 Metaphor describes a person or object in a literary way by referring to something that is considered to have similar characteristics to the person or object that is trying to be described.

Data 2

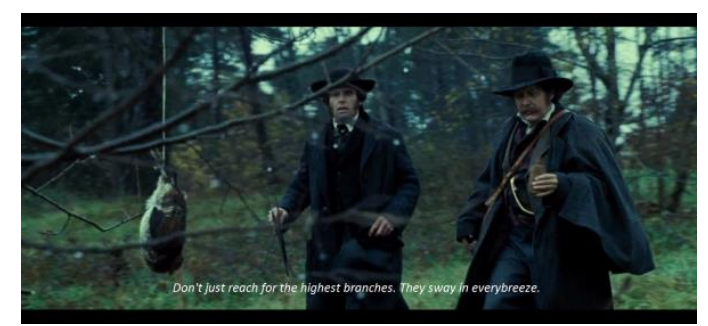

Clay Hawkins : T-tax collector for the

Western Reserve. Th-th-that pays handsomely.

W.N. Bilbo: Don't just reach for the highest branches. They sway in everybreeze. Assistant Port Inspector of Marlston looks like the ticket to me.

Clay Hawkins: Uh, boats, they, they make me sick.

W. N. Bilbo, one of the men who offered a service on behalf of congressional approval of the thirteenth amendment, and Clay Hawkins, a fictional character who is portrayed as a congressman of Ohio and the member of Democrat Party. They have a conversation about the job offers. Hawkins states tax collector for the Western Reserve as the price for his vote. However, Bilbo later says 'Don't just reach for the highest branches. They sway in every breeze' and offers a job to be an Assistant of Port Inspector of Marlston. The screenshot above shows Bilbo's and Hawkins' talking secretly in the woods. Moreover, it shows when Bilbo flouted the maxim of relevance to give advice to Hawkins about the position that Hawkins wanted.

In this conversation, Bilbo has done a relevance maxim flouting since he does not make his contribution relevant for the purpose of the exchange. Metaphor is the strategy applied by Bilbo in flouting the maxim. Here, Bilbo draws a comparison between the high job positions and the highest branches of tree. Both of them are considered similar because they easily are affected in every situation. Bilbo advises Hawkins not to just reach the highest job position because it is easily affected by the situations, such as economy and political situation. The reason Bilbo flouts maxim of relevance is to make Hawkins realize that the high job position is not as good as the job he offered, in this case the job to be the Assistant of Port Inspector of Marlston is more appropriate for Hawkins according to Bilbo.

5.3 Rhetorical Question uses question to make statement and force the listener to interpret the question to understand the message. 


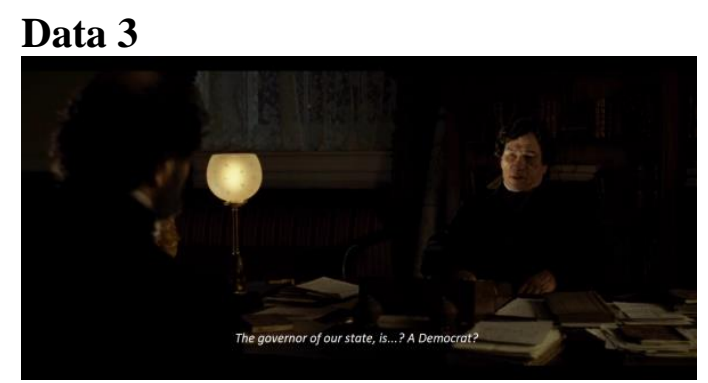

Thaddeus Stevens: The modern travesty of Thomas Jefferson's political organization to which you have attached yourself like a barnacle has the effrontery to call itself The Democratic Party. You are a Dem-o-crat. What's the matter with you? Are you wicked?

Alexander Coffroth: Well, I felt, um, formerly, I -

Thaddeus Stevens: Never mind, Coffsnot. You were ignominiously trounced at the hustings in November's election by your worthy challenger, a republican -

Alexander Coffroth: No, sir, I was not, um, trounced! Uh, he wants to steal my seat! I didn't lose the election -

Thaddeus Stevens: What difference does it make if you lost or not?! The governor of our state, is...? A Democrat?

Alexander Coffroth: No, he's a... A, um, a Ruh...

Thaddeus Stevens, one of the leaders of Radical Republican faction of Republican Party, is in his office when Alexander Coffroth, member of Democrat Party, knocks at the door of his room. Since Coffroth lose on the previous election for the next term of congress, the lobbyists advised Coffroth to pay a visit to Stevens if he hopes to retain his seat. As Coffroth enters the room, Stevens glares at him and makes the situation tense. Stevens keeps intimidating Coffroth by not noticing Coffroth's existence as the member of House of Representative, calling Coffroth's name wrongly, asking question but not letting Coffroth finish his answer, insulting Coffroth's party, namely Democrats Party, and asking questions: 'The governor of our state, is...? A Democrat?' and 'And Congress is controlled by what party? Yours?'.

In this conversation, Stevens is being irrelevant. In terms of maxim flouting, Stevens has done relevance maxim flouting. The strategy applied by Stevens is rhetorical question. By asking questions that have no intention to seek answers when they are talking about Coffroth's lost on the election. Those questions are used to make statement, not to get an answer. The answer of both of the questions asked is Republican Party and Stevens actually already knew the answer. The reason Stevens flouts the maxim of relevance is to intimidate and threaten Coffroth. The questions asked are meant to make Coffroth realize how unfavorable his position is.

5.4 Irony suggests a different meaning from what is said by the speaker.

\section{Data 4}

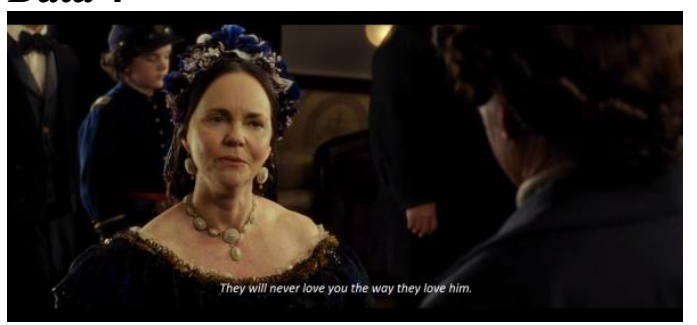

Mary (Continued): The past is the past, it's a new year now and we are all getting along, or so they tell me. I gather we are working together! The White House and the other House. Hatching little plans together.

Robert : Mother.

Mary : What?

Robert : You're creating a bottleneck. 
Mary : (To Stevens) Oh! I'm detaining you, and more important, the people behind you! How the people love my husband, they flock to see him, by their thousands on public days! They will never love you the way they love him. How difficult it must be for you to know that. And yet how important to remember it.

In the Grand Reception party, the first lady, Mary Todd Lincoln, and Thaddeus Stevens are engaged in a tension-filled conversation. At first they talk about Mary's interesting household account; however, later she continues talking about when her account was investigated by the committee proposed by Stevens and assumes that Stevens, his committee, and the whole Washington is waiting for her and her husband to make mistake as a proof that they do not deserve the position. When she was about to finish her utterances, she says 'They will never love you the way they love him'. Moreover, she takes pity for Stevens by saying 'How difficult it must be for you to know that. And yet how important to remember it' as well.

In this conversation, Mary has done a quality maxim flouting since she does not make his contribution true for the purpose of the exchange. The strategy applied by Mary to flout the maxim of quality in this exchange is sarcasm. When Mary is about to end her conversation with Stevens, she intentionally states a contribution that is not true and lacks adequate evidence by saying that Stevens will never be loved by the people the way they love her husband and he has to accept that reality. Mary expresses her statement unfriendly and she intends to offend Stevens. The reason Mary flouts maxim of quality is to insult Stevens that he has to accept the reality because he will never be able to surpass her husband.

\section{Conclusion}

With regard to the data analysis dealing with the strategies of maxim flouting, four of six strategies of maxim flouting were applied in the movie script; they are: overstatement, metaphor, rhetorical question, and irony. Using those four applied strategies of maxim flouting, the characters in movie script could describe something stronger than is warranted by the state of affairs described, describe a person or object with another thing which has similar characteristic, make a statement with a question, and being offensive in a friendly way or vice versa. The two strategies of maxim flouting that were not applied are tautology which allows a speaker to express a relatively complex meaning in an easier way, and understatement which allows a speaker to describe something weaker than the actual state of affairs.

In terms of reasons for maxim flouting, various intentions that lead the characters to flouting or intentionally breaking one of conversational maxims to lead the listener to finding a hidden meaning were found in the movie script; they are: demanding, offering, accusing, reprimanding, cursing, threatening, announcing, instructing, greeting, reporting, asserting, and insulting reason.

The characters who flout the maxim the most in the movie script are Abraham Lincoln and Mary Todd Lincoln. The most flouted maxim in the movie script is quality maxim. The strategy of maxim flouting that flouted the most in the movie script is irony. Insulting is the most reason of maxim flouting applied by the characters in Lincoln movie script. 


\section{Bibliography}

Grundy, P. (2013). Doing Pragmatics. Third Edition. Routledge, New York.

Grice, H. P. (1975). Logic and Conversation. Syntax and Semantic 3: Speech Acts, 3, 41-58 [Internet]. Available from: http://www.ucl.ac.uk/ls/studypacks/ Grice-Logic.pdf [Accessed 16 February 2017].

Yule, G. 1996. Pragmatics. Oxford University Press, Oxford. 